\title{
OS MEGAEVENTOS ESPORTIVOS NO BRASIL E O USO CORPORATIVO DO TERRITÓRIO: O CASO EMBLEMÁTICO DA VILA AUTÓDROMO NO RIO DE JANEIRO
}

\author{
Roberto Paolo Vico \\ Universidade Federal do Rio Grande do Norte \\ roberto.paolo.vico@gmail.com \\ Francisco Fransualdo de Azevedo \\ Universidade Federal do Rio Grande do Norte \\ ffazevedo@gmail.com
}

\begin{abstract}
RESUMO
O uso dos territórios pelas grandes empresas e organizações esportivas internacionais tende atualmente a ocorrer de acordo com seus interesses e demandas que são cada vez mais influenciadas pelo capital internacional. Deste modo, a utilização de espaços selecionados do território nacional fica submetido a uma dinâmica que, por intermédio de instituições e empresas internacionais e com a tutela do Estado e dos governos locais, acaba se subordinando a uma lógica global. Este artigo tem como campo de estudo o fenômeno dos megaeventos esportivos como instrumentos de transformações socioterritoriais, problematizando de que forma as grandes organizações esportivas internacionais como a FIFA e o COI, junto com seus parceiros comerciais e o Estado, utilizam e planejam o espaço geográfico brasileiro para fins de realização dos megaeventos esportivos. Ao longo do estudo abordam-se questões relativas ao uso corporativo hierárquico do território pelos grandes grupos e organizações esportivas e os efeitos derivantes, com particular ênfase nos recentes megaeventos esportivos no Brasil: Copa do Mundo de Futebol de 2014 e Jogos Olímpicos do Rio de Janeiro de 2016. Finalmente aborda-se o caso de estudo da Vila Autódromo, na Zona Oeste do Rio de Janeiro, como exemplo de significativa transformação do espaço pelos megaeventos esportivos.
\end{abstract}

Palavras-chave: Olimpíadas. Impactos. Remoções. Conflitos territoriais. Resistência.

\section{THE SPORTS MEGA-EVENTS IN BRAZIL AND THE CORPORATE USE OF THE TERRITORY: THE EMBLEMATIC CASE OF VILA AUTÓDROMO IN RIO DE JANEIRO}

\begin{abstract}
The use of territories by large corporations and international sports organizations is currently occurring according to their interests and demands that are increasingly influenced by international capital. In this way, the use of selected spaces in the national territory is subjected to a dynamic that, through international institutions and companies and with the protection of the State and local governments, ends up being subordinated to a global logic. This article has as a field of study the phenomenon of sports mega-events as instruments of socio-territorial transformations, problematizing how large international sports organizations like FIFA and IOC, together with their trading partners and the State, use and plan the Brazilian geographic space for the purpose of performing the mega-sport events. Throughout the study, questions are raised regarding the hierarchical corporate use of the territory by large groups and sports organizations and the deriving effects, with particular emphasis on the recent sports mega-events in Brazil: the 2014 Football World Cup and the 2016 Rio de Janeiro Olympic Games. Finally, the study case of the Vila Autódromo, in the West Zone of Rio de Janeiro, as an example of a significant transformation of space by sports mega-events.
\end{abstract}

Keywords: Olympic Games. Impacts. Removals. Territorial conflicts. Resistance.

\section{INTRODUÇÃO}

A cidade moderna está inserida num cenário global cada vez mais determinado pelo fenômeno da mundialização das forças produtivas capitalistas, sendo caracterizada por um crescimento

$\begin{array}{lllll}\text { Caminhos de Geografia } & \text { Uberlândia-MG } & \text { v. 21, n. } 74 & \text { Abr/2020 } & \text { p. 108-125 Página } 108\end{array}$


exponencial da competição urbana internacional. A mundialização constitui um elemento determinante pela requalificação econômica urbana (CHESNAIS, 1996).

Assim sendo, através dos megaeventos que representam acontecimentos de natureza global, as urbes promovem importantes mudanças dos próprios sistemas físicos, econômicos e sociais e, consequentemente, da própria imagem. São transformações que pressupõem um delicado planejamento e elevados investimentos econômicos. Neste contexto, as cidades são compelidas a lidar com os diversos problemas externos e internos, nas diversas escalas geográficas em nível local e global. Hiller (2000), em particular, reconhece que os megaeventos são um fenômeno particularmente urbano, e que a mundialização e a reestruturação econômica das cidades foram dois potentes fatores de atratividade dos mesmos. Isso está confirmado por vários autores e estudos de caso. Por exemplo, no passado mais recente, cidades como Lisboa (Expo de 1998), Pequim (Olimpíadas de 2008), Londres (Jogos Olímpicos de 2012), Milão (Expo de 2015) e Rio de Janeiro (Olimpíadas de 2016), entre outras, candidataram-se e acolheram megaeventos cujo objetivo principal devia ser a regeneração da própria urbe, ou de áreas que antes eram consideradas zonas industriais ou periféricas da cidade. Contudo, Hiller (2000) afirma que a internacionalização do capital pode utilizar o megaevento como uma forma de marketing do lugar onde se realiza, tendo em vista os investimentos internos. Está amplamente reconhecido que o território e o contexto local são determinantes em termos de força competitiva. É verossímil que também algumas das cidades oferecem uma melhor combinação de atributos para as empresas do que outras.

Alguns autores consideram que, em termos puramente econômicos, dever-se-ia afirmar que são as empresas que competem, e não as cidades ou as regiões enquanto tais (VAINER, 2000). De outro lado, o contexto econômico pode ter um impacto significativo sobre a capacidade de competição das empresas considerando a sua eficácia neste sentido. O potencial da política sobre este contexto poderia ser muito limitado, pois o clima econômico responde àqueles que são os efeitos da concorrência, das mudanças estruturais da economia e dos desenvolvimentos tecnológicos (CHESNAIS, 1996).

Ao nível das regiões ou das áreas urbanas, a força competitiva pode ser vista também em termos do crescimento ocupacional e atração de investimentos externos. Concomitantemente, para alcançar os efeitos desejados, os territórios devem elevar a própria notoriedade e atratividade, propondo estilos de vida que respondam às necessidades dos cidadãos, turistas ou investidores. Neste contexto, os megaeventos servem justamente para elevar a visibilidade de um território dotando-o de infraestruturas e também para acelerar o processo de transformação urbana com base nos próprios projetos de requalificação, mas em geral com custos sociais muito elevados.

Assim, o presente estudo tem como objetivo compreender de uma forma geral como se dá o uso corporativo do território que é anfitrião de um megaevento, pelas principais organizações esportivas internacionais como a Fédération Internationale de Football Association (FIFA), o Comitê Olímpico Internacional (COI) e o Comitê Olímpico do Brasil (COB), bem como por seus principais parceiros comerciais internacionais, analisando em particular o caso da Vila Autódromo na Zona Oeste da cidade do Rio de Janeiro.

Do ponto de vista metodológico, a análise apresentada baseou-se fundamentalmente em revisão bibliográfica, utilização de reportagens jornalísticas recentes e entrevistas exploratórias e estruturadas junto a pesquisadores, professores, profissionais da área e indivíduos que já trabalharam na gestão de um megaevento ou tiveram um papel importante. Além disso, desenvolveu-se também uma análise do discurso e do conteúdo derivante do depoimento de alguns sujeitos da pesquisa entrevistados em Natal (Rio Grande do Norte) e na comunidade da Vila Autódromo no Rio de Janeiro. Utilizou-se como referencial teórico para a discussão sobre o território, autores como Santos e Silveira, os quais abordam o debate sobre a nova forma de produção espacial da cidade a partir do desenvolvimento econômico, exigindo que esses espaços assumam características corporativas de modo que atenda às demandas do mercado.

O presente artigo está dividido em três partes. Na primeira parte ressaltam-se os aspetos teóricos baseados nas teorias de Milton Santos e de Maria Laura Silveira concernentes a importância da técnica para as cidades modernas, a divisão territorial do trabalho, os circuitos da economia urbana dos países subdesenvolvidos e, em particular, aprofunda-se a questão do uso corporativo hierárquico e vertical que é feito do território pelas grandes empresas, organizações esportivas como a FIFA, o $\mathrm{COI}, \mathrm{o} \mathrm{COB}$ e os seus parceiros comerciais. Analisam-se, também, segundo uma perspetiva legal, algumas leis e acordos que os governos e as autoridades locais promulgaram, favorecendo o uso 
corporativo do território pelas grandes organizações esportivas internacionais. Frequentemente estas leis configuram-se como direitos excecionais, fora ou adicionais às leis em vigor na própria Constituição de um país. Em particular, no trabalho, examinam-se a "Lei Geral da Copa" e o "Ato Olímpico". Na segunda parte é apresentado o caso emblemático da Vila Autódromo, comunidade na zona Oeste do Rio de Janeiro que vive numa constante luta em busca dos seus direitos contra as remoções e expropriações por causa da valorização e especulação imobiliária relacionadas com os recentes megaeventos esportivos. Enfim, na última secção são apresentadas as considerações finais.

\section{FUNDAMENTAÇÃO TEÓRICO-CONCEITUAL}

\section{O uso corporativo do território no contexto dos recentes megaeventos esportivos no Brasil}

Segundo Silveira (2010), a competitividade que permeia as cidades associa-se à formação do meio técnico-científico-informacional onde são desenvolvidas as principais tarefas de concepção técnica, informacional, mercadológica e a transformação dos instrumentos financeiros (SILVEIRA, 2010). De acordo com a autora, não se trata simplesmente de uma extensão dos contextos, onde todas as cidades são convidadas a produzir e competir ativamente. Existe, na verdade, uma multiplicidade e coexistência de divisões do trabalho que acrescentam o uso do território; possuindo como condição e resultado a configuração de fixos e fluxos como as infraestruturas, os movimentos de população, a base normativa, a dimensão da cidadania e as diferentes dinâmicas agrícolas, industriais e de serviços (SILVEIRA, 2010). Segundo esta lógica, o espaço geográfico constitui, portanto "um rendilhado de divisões territoriais, um sinônimo de território usado" (SILVEIRA, 2010, p.74) e, consequentemente, "a soma dos resultados da intervenção humana sobre a terra" (SANTOS, 2012, p. 29).

Portanto, os novos subespaços, inscritos nessa dinâmica, não possuem uma capacidade homogênea para rentabilizar determinada produção, pois, cada combinação detém sua própria lógica, consentindo formas de ação e atores envolvidos, muitas vezes específicos para cada contexto (SANTOS, 2012). Desse modo, dependendo das circunstâncias locais de natureza organizacional e técnica, as cidades se distinguiriam adquirindo uma vantagem competitiva pela sua capacidade individual, maior ou menor, de rentabilizar investimentos. Esta vantagem, segundo Santos, não representa uma peculiaridade absoluta do lugar, pois a eficiência produtiva estaria relacionada à uma atividade preponderante própria. Isso indica que as cidades devem especializar-se em uma determinada direção usufruindo da capacidade técnica e organizacional e das próprias características distintivas em nível socio-territorial e cultural. Emerge, portanto uma grande competitividade entre as cidades e os vários agentes envolvidos.

Para Santos (1992), hoje em dia o mundo encontra-se estruturado em subespaços articulados numa lógica global, cada lugar configura-se como fruto de uma ordem global e de uma ordem local, convivendo dialeticamente. Como consequência dos diversos fluxos e fixos, intensidades e direções, quebram-se os equilíbrios anteriores. Portanto, segundo esta ótica, não são somente as cidades que competem entre elas, mas também as empresas, as quais tornaram-se verdadeiras empresas globais que "se valem dos progressos científicos e técnicos disponíveis no mundo e pedem, todos os dias, mais progresso científico e técnico" (SANTOS, 2004, p.15). Uma das peculiaridades desse novo contexto de globalização é a criação de condições para uma maior circulação de pessoas, produtos e serviços, mercadoria, dinheiro e informação (SILVEIRA, 2016). Por isso, os países procuram dotar-se de novos tipos de infraestrutura, modernização do sistema de transporte e da mobilidade urbana, de aquisição de novas tecnologias e know-how. E uma das estratégias para tentar aumentar o próprio progresso tecnológico e nível de infraestrutura por parte dos países e aumentar o próprio know-how consiste em candidatar-se para organizar e acolher um megaevento.

Conforme Santos e Silveira (2001), cada atividade ou empresa precisa de lugares que determinam a base geográfica da sua existência, desenvolvendo desse modo a sua própria divisão do trabalho. Mas, algumas atividades ou corporações utilizam o espaço segundo lógicas globais (grandes organizações esportivas internacionais e os seus principais parceiros comerciais) e outras operam a partir de lógicas nacionais ou até intraurbanas. As empresas globais, segundo a dinâmica da divisão do trabalho, entram em competição mas, ao mesmo tempo, colaboram formando "clusters" e cooperando na lógica do trabalho "coletivo" no território. 
Não será exagero dizer que estamos diante de um verdadeiro comando da vida econômica e social e da dinâmica territorial por um número limitado de empresas. Assim, o território pode ser adjetivado como um território corporativo, do mesmo modo que as cidades também podem ser chamadas de cidades corporativas, já que dentro delas idênticos processos se verificam (SANTOS e SILVEIRA, 2001, p. 291).

Assim como acontece com os megaeventos, estas empresas e/ou organizações, possuem uma influência e um alcance global tanto que pode-se falar de uma exportação do território em nível planetário (SANTOS e SILVEIRA, 2001). "As empresas procuram em cada território nacional a localização que mais lhe convém" (SILVEIRA, 2009, p. 441-442), procurando pontos de interesse aptos para suas atividades, consequentemente para a acumulação de lucro. Nesse âmbito, a metáfora cidade-empresa, proposta por Vainer (OLIVEIRA, 2013, p. 18), "perde a condição de metáfora, quando a cidade não é mais apenas gerida tal qual uma empresa, mas é a própria empresa privada que responde diretamente pelo planejamento e gestão da cidade". Esse mesmo raciocínio se aplica também para aquelas empresas envolvidas no segmento dos megaeventos esportivos, a seguir, assim como ilustrado na Figura 1, alguns exemplos dos principais parceiros comerciais da FIFA e do COI: Coca-Cola, Budweiser, Visa, Nike, Adidas, Toyota, Bradesco, Bradesco Seguros, Claro, Embratel, Net, Nissan, Wanda, Samsung, Omega, Bridgestone, McDonald's, Panasonic, Correios etc.

Figura 1 - Principais patrocinadores e parceiros comerciais da FIFA e do COI nos recentes megaeventos do Brasil.

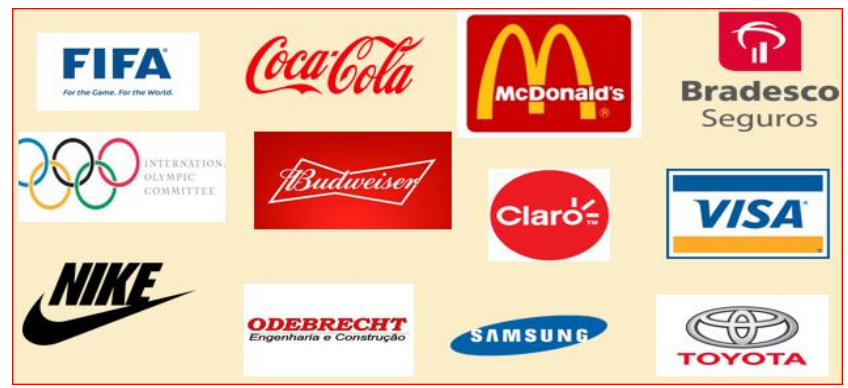

Fonte - Adaptado de O ESTADÃO DE SÁO PAULO (2017).

Desse modo, de acordo com Silveira:

Cada empresa, cada ramo de atividade produz uma lógica territorial, cuja manifestação visível é uma topologia; ou seja, aquele conjunto de pontos e áreas de interesse para o funcionamento da empresa que, certamente, supera a própria empresa e é projetado em outros atores sociais (SILVEIRA, 2007, p. 24).

Portanto se cria assim uma espécie de guerra global entre os lugares, ou seja, uma competição global de empresas que buscam lugares produtivos. De fato os lugares com as suas próprias materialidades, fixos, culturas, tradições, regras, normas fiscais etc. constituem, segundo Silveira (2007, p. 24), "Verdadeiros tecidos que atraem ou rejeitam certos locais corporativos". A maioria dos países subdesenvolvidos configura o mercado interno como "residual" e a dinâmica do mercado global acaba influenciando fortemente também o mercado interno. Assim sendo, as grandes firmas e multinacionais internacionais acabam tendo um controle parcial sobre o território com base em interesses próprios particulares. A presença de uma grande firma no território influencia diferentes aspectos como: a imagem e a visibilidade da localidade / destino, a ética com os comportamentos individuais e coletivos, os empregos, o consumo, os gostos, as infraestruturas, o know-how, o conhecimento e sobretudo as técnicas e a tecnologia.

Nesse contexto Santos e Silveira, (2001, p. 289) introduzem o conceito de "ordem espacial" salientando que "quando falamos de ordem espacial, estamos novamente nos referindo ao espaço explicado pelo seu uso. Cada momento da história tende a produzir sua ordem espacial, que se associa a uma ordem econômica e a uma ordem social". Contudo, esta ordem espacial é principalmente "submetida ao papel regulador de instituições e empresas". 
As empresas globais, responsáveis e/ou promotoras dos megaeventos esportivos, podem identificarse com as grandes organizações e associações esportivas, em primeiro lugar a FIFA para a organização dos Campeonatos Mundiais de Futebol e a Taça das Confederações e o COI para os Jogos Olímpicos, assim como todos os seus grandes parceiros comerciais internacionais e locais citados anteriormente. Tais organizações esportivas dispõem de uma área de atuação muito vasta que engloba diferentes regiões, países e até continentes. É suficiente, pois, pensar como as sedes principais da FIFA e do COI estejam situadas na Suíça, organizando as próprias manifestações esportivas de quatro em quatro anos em países e localidades diferentes, e que, em nível nacional, utilizam o seu próprio serviço distribuído em um grande número de pontos de interesse (as cidadessede) e em diferentes bairros de atuação que, no caso dos Jogos Olímpicos do Rio de Janeiro de 2016, coincidiram com os bairros de Jacarepaguá, Barra da Tijuca, Maracanã, Copacabana, Centro / Zona Portuária, Deodoro entre outros.

Como dito, algumas cidades ou países são reconhecidos pela FIFA e pelo COI como as mais aptas para a organização e realização do evento. Isso cria uma competitividade internacional entre as cidades. "Algumas zonas mais propícias para sediar atividades de nível global se tornam autênticos espaços da globalização" (SANTOS e SILVEIRA, 2001, p. 299). Esta escolha estratégica de países, cidades e bairros por parte das organizações esportivas cria ou aumenta a segregação socio-espacial e as desigualdades, favorecendo algumas localidades e prejudicando outras que tornam-se sempre mais esquecidas e com populações mais pobres (SANTOS e SILVEIRA, 2001; HARVEY, 2009). Trata-se de uma lógica que deriva das mudanças neoliberais nos territórios. Estas associações escolhem os lugares que consideram funcionais para a própria existência produtiva (HARVEY, 2005; BRENNER, 2014). "É uma modalidade de exercício do seu poder" (SANTOS e SILVEIRA, 2001, p. 294).

Os lugares que não são tomados em consideração são chamados de "espaços opacos" ou "zonas de rarefação" enquanto os outros seriam os "espaços luminosos" ou "zonas de densidade". Portanto, pode-se afirmar que somente alguns pontos do território são impactados diretamente pelas grandes organizações esportivas e seus principais parceiros comerciais enquanto os outros pontos ou secções territoriais não são influenciados.

Tudo isso cria uma dinâmica de construção/destruição que Santos e Silveira (2001) definem de revalorização e desvalorização do território no âmbito também da lógica da competitividade global. Trata-se, então, de uma verdadeira busca por lugares produtivos. O território deve ser considerado como único, solidário e sensível. Ao ponto que, o uso que é feito pelas grandes corporações e organizações esportivas para a organização e realização de um megaevento das dimensões dos Jogos Olímpicos, cria valorização de algumas áreas e desvalorização de outras, determinando dessa forma mudanças e transformações substanciais.

Viu-se como na contemporaneidade existe um grupo de firmas cuja topologia ultrapassa a dimensão nacional e cujo território é constituído pelo mundo inteiro. Se trata de empresas globais e multinacionais. Mas, ao mesmo tempo, sobrevivem também as pequenas empresas que pertencem ao circuito inferior da economia urbana, numa escala nacional, mas também ao nível local como as pequenas empresas de bairro. Estas duas tipologias de empresas coexistem e atuam segundo dinâmicas que são ao mesmo tempo de cooperação e conflito.

De fato, pode-se considerar os grandes grupos e corporações como organizações poderosas que detêm o poder hegemônico, enquanto as outras empresas são subordinadas àquelas de algum modo. As firmas globais prevalecem e evidenciam a própria hegemonia, sobretudo pelo que concerne as tomadas de decisões, como, por exemplo, ao nível dos projetos urbanos de transformação do tecido de uma cidade, da construção de novas infraestruturas e rodovias, e de como serão utilizadas e regulamentadas. Conforme afirma Silveira:

\begin{abstract}
Não é exagero dizer que hoje, quando a divisão territorial do trabalho em um país é globalizada, o poder das empresas regula a vida política da nação, impondo suas respetivas topologias no território nacional e forçando formas de cooperação; isto é, modernizar infraestruturas, aumentar a velocidade e a fluidez material e normativa, demandas tantas vezes estranhas às verdadeiras necessidades nacionais (SILVEIRA, 2007, pp. 16-17).
\end{abstract}

Portanto o poder dessas empresas alcançou um vigor tão elevado que pode-se falar de uso corporativo do território. Essas firmas são detentoras da tecnologia e dos últimos avanços da tecnociência, além de gerarem a informação que precisam e aquela que serve para influenciar os

$\begin{array}{lllll}\text { Caminhos de Geografia } & \text { Uberlândia-MG } & \text { v. 21, n. 74 } & \text { Abr/2020 } & \text { p. 108-125 Página } 112\end{array}$


outros de forma hegemônica e vertical. Segundo Santos e Silveira (2001), na realidade, infelizmente, as grandes empresas operam seguindo uma dinâmica de tipo vertical, do alto para baixo, e as fases essenciais das atividades estão relacionadas fundamentalmente aos interesses e prioridades desses grandes grupos, criando espécies de "oligopólios territoriais".

Sem dúvida, o território como um todo e as cidades em particular acolhem uma tipologia de atividades. Muitas delas são mais fortemente relacionadas com o próprio território e, portanto, mais dependentes da sociedade próxima e das virtualidades materiais e sociopolíticas de cada área, o que permite certa horizontalização da atividade. O papel de comando, todavia, é reservado às empresas dotadas de maior poder econômico e político, e os pontos do território em que elas se instalam constituem meras bases de operação, abandonadas logo que as condições deixam de lhes ser vantajosas. As grandes empresas, por isso mesmo, apenas mantêm relações verticais com tais lugares. (SANTOS e SILVEIRA, 2001, p. 291).

Dessa forma, pode-se destacar que a divisão territorial do trabalho hegemônico vem de um evento hierárquico, definido por eventos que vêm de longe como ordens e normas " (SANTOS, 1996 apud SILVEIRA, 2009, p. 452). Contudo, essas grandes corporações e associações têm como objetivo primário somente o lucro desesperado, a tão esperada mais-valia, possuindo motivações meramente egoísticas e privadas de qualquer forma de teleologia. Elas atuam segundo um instinto animal do "peixe grande que come o peixe pequeno", sendo o peixe pequeno, nesse caso, a população local e todos os outros sujeitos não hegemônicos (SANTOS, 2008) como: pequenas comunidades, empresas e lojas menores, vendedores ambulantes e "camelôs", artesãos etc. Estes sujeitos são marginalizados, afastados do raio espacial onde acontece o megaevento e relegados a posições menos produtivas. Portanto, "cada lugar, como cada região, deve ser considerado um verdadeiro tecido no qual as condições locais de infraestrutura, recursos humanos, fiscalidade, organização sindical, força reivindicatória afastam ou atraem atividades em dado momento" (SANTOS e SILVEIRA, 2001, p. 297).

Dessa forma, inspirando-se nas ideias marxistas de produção necessária e de produção desnecessária (MARX, 1983, 1984), Santos e Silveira ressaltam como "esse tema pode ser visto segundo um critério moral: a produção necessária seria a que ajuda a população a subsistir e a se desenvolver, enquanto a produção desnecessária seria não apenas o excedente, mas também excessiva, acarretando para a sociedade um ônus desnecessário" (SANTOS e SILVEIRA, 2001, p. 297).

No caso dos megaeventos esportivos, o $\mathrm{COI}$ e a FIFA encorajam a construção de obras de modernização, infraestruturas, transporte e mobilidade urbana que as cidades necessitam para a realização do megaevento, "fortalecendo o processo de produção do espaço corporativo" (SANTOS e SILVEIRA, 2001, p. 295) e desenvolvendo um papel fundamental na produção e no financiamento do território e da economia.

Porém, essas intervenções muitas vezes representam obras desnecessárias realizadas somente para legitimar os elevados investimentos e, dessa forma, poder desviar verba ativando mecanismos de corrupção. Além disso, constituem obras que possuem altos custos de manutenção, como é o caso, por exemplo, dos estádios, das arenas e de outras instalações esportivas e que frequentemente têm uma fraca utilização depois do megaevento (como os famosos elefantes brancos ou catedrais no deserto).

Essex e Chalkley (2004) também questionam se as instalações esportivas e as infraestruturas de apoio aos eventos podem ser úteis para o território anfitrião, no momento em que estas intervenções não foram previstas nem constituíam uma prioridade para o território. Por um lado, heranças como o crescimento econômico, o aumento dos fluxos turísticos, as melhorias dos serviços de transporte, culturais e ambientais e o maior prestígio em nível mundial, podem ser positivas, embora nem sempre sejam. Por outro lado, o impacto gerado pela construção de instalações esportivas e de novas estruturas, além do efeito positivo sobre a economia e sobre o mercado de trabalho, pode ser menos útil ou totalmente negativo, no momento em que se pode verificar remoções de famílias de moradores, desperdícios de investimentos, desvios de verba e de recursos, e a necessidade de dever enfrentar as dívidas acumuladas (VICO, 2016; VICO et al., 2018).

Frequentemente estes investimentos são realizados com recursos públicos e provocam um consequente endividamento por parte do Estado, o que constitui um verdadeiro custo social para a nação/cidade anfitriã com uma carga pesada para a sociedade a ser descontada até muitos anos

\begin{tabular}{|c|c|}
\hline Caminhos de Geografia & Uberlândia-MG \\
\hline
\end{tabular}


depois da realização do megaevento, fato que incide fortemente sobre o bem-estar geral da população. Este custo social se reflete, sobretudo, nos países subdesenvolvidos onde ainda permanecem muitas desigualdades e problemas sociais como sistemas de educação e de saúde precários, falta de saneamento básico, moradias/habitações, problemas relacionados com o crime e a segurança e a falta de emprego entre outros.

Conforme Silveira (2009), o espaço é usado por vários intervenientes ou agentes que frequentemente interagem e entram em conflito entre eles. $E$ através de objetos e ações que se desenvolve o trabalho. "Considera-se o espaço geográfico como uma rede de divisões territoriais do trabalho, um sinônimo de território usado" (SILVEIRA, 2009, p. 436).

A maneira em que o espaço é utilizado pela sociedade com as diferentes formas de envolvimento e inclusão das pessoas, é indicada pela formação sócio-espacial (SILVEIRA, 2009). Tornam-se relevantes nesse período, novas maneiras de usar e partilhar o espaço pelos diferentes atores envolvidos no processo, provocando distorções e fragmentações do território. Estes grandes grupos internacionais criam verdadeiros laços de cooperação que envolvem o espaço sob a forma de ordens, informações, publicidade, dinheiro e estratégias financeiras. Tais laços representam os círculos de cooperação e são consideradas as etapas imateriais pelas quais passa o processo produtivo e a moderna divisão do trabalho (SILVEIRA, 2009). Trata-se, então, de uma cooperação que tem uma natureza particularmente intangível, constituída, sobretudo pela informação e pelas finanças.

O território, portanto, se torna dependente de empresas e agentes estranhos à própria realidade e cuja operação obedece a normas que não concernem nem respeitam os valores sociais locais e que não se preocupam com a população local como, por exemplo, através do envolvimento dos moradores e dos seus valores sociais.

Cria-se, assim, um processo de crescimento no território que Santos e Silveira (2001, p. 300-301) definem como um "processo alienado" constituído por um "conjunto de alienações" e "teatro de divisões de trabalho superpostas" provocando uma verdadeira "guerra global" entre firmas, organizações esportivas, corporações, pequenos agentes, comunidade local e lugares. "O que resulta na prática é a vitória de uma lógica econômica a despeito das distorções de ordem social que possa acarretar. A consequente divisão do trabalho passa a ser comandada de fora do interesse social (SANTOS e SILVEIRA, 2001, p. 298).

Segundo Silveira (2009), essa pluralidade de divisões sociais e espaciais do trabalho poderia ser vista como um ativo e um capital e não como uma barreira para superar. De fato diferentes atores indica a combinação de várias formas de produção e diferentes mercados, tornando mais sólido e menos vulnerável o tecido social e espacial. Tudo isso não somente através do crédito, mas também pela existência de mercados plurais em maneira tal que os vários atores envolvidos possam coexistir em uma reciprocidade de ofertas e demandas, mesmo se com uma velocidade de operação diferente (SILVEIRA, 2009).

Porém, os diferentes interesses dos vários intervenientes, geram uma grande instabilidade do território, causando protestos, manifestações e um mal-estar geral por parte da população residente como já aconteceu para a Taça das Confederações de 2013, para a Copa do Mundo de Futebol de 2014 e também antes e depois da realização dos Jogos Olímpicos do Rio de Janeiro. É sabido, nessa perspetiva, que relativamente à gestão de um megaevento, a concentração das atividades comerciais reside nas mãos de um número reduzido de empresas, parceiras da FIFA e do $\mathrm{COI}$ ou indicadas e favorecidas pelos governos locais que constituem os beneficiários diretos dos megaeventos. São um grupo de agentes que engloba desde as empresas de construção, as empreiteiras, os bancos, engenheiros, arquitetos, passando pelas empresas de segurança, de bebidas e alimentação, aos meios de comunicação, telecomunicação e telefonia, até profissionais de diversos setores da sociedade envolvidos na promoção de um megaevento esportivo (publicidade, marketing, relações públicas, etc.).

Neste leque de atores, se beneficiam usualmente as grandes multinacionais (muita das vezes ligadas à FIFA e ao COI, como a Coca Cola, a Budweiser, a Visa, o McDonald's, as agências de desenvolvimento do território, os bancos, as empresas imobiliárias, as grandes construtoras e empreiteiras (no Brasil a Odebrecht, a Camargo Correia e a OAS, principalmente), as empresas de mídia (no Brasil a Rede Globo e a Editora Abril), de telefonia (Embratel, Claro etc.), as seguradoras (Bradesco Seguros) e também todos os que possam trazer vantagem pelo aumento e pela especulação do mercado imobiliário (EGLER, 2017). Estes grandes grupos impõem preços mais altos 
aos bens e produtos e, na maioria das vezes com uma qualidade também mais baixa (SANTOS e SILVEIRA, 2001; SANTOS, 2008).

No quadro 1 observa-se as receitas dos principais setores de atuação dos patrocinadores brasileiros durante os Jogos Olímpicos do Rio de Janeiro.

Quadro 1 - Receita prevista de patrocinadores locais dos Jogos Olímpicos de 2016.

\begin{tabular}{|c|c|c|c|}
\hline PRIMEIRO NIVEL & SEGUNDO NIVEL & \multicolumn{2}{|c|}{ TERCEIRO NÍVEL } \\
\hline $\begin{array}{l}\text { Patrocinadores } \\
\text { Nacionais }\end{array}$ & Parceiros & \multicolumn{2}{|c|}{ Fornecedores } \\
\hline 10 x 30 milhões US\$ & $10 \times 14$ milhões US\$ & \multicolumn{2}{|c|}{20 x vários valores } \\
\hline Mineração & $\begin{array}{c}\text { Indústria } \\
\text { automobilística }\end{array}$ & Atendimento médico & Serviço de idiomas \\
\hline Petróleo & Companhia aérea & Hotel & Móveis \\
\hline Telecomunicações & $\begin{array}{l}\text { Gás industrial e } \\
\text { natural }\end{array}$ & Tintas & $\begin{array}{c}\text { Fornecedores de material } \\
\text { de escritório }\end{array}$ \\
\hline Alimentos embalados & Transporte público & Material elétrico & Serviços de impressão \\
\hline Bancos & $\begin{array}{c}\text { Indústria } \\
\text { farmacêutica }\end{array}$ & Confeitaria & $\begin{array}{c}\text { Equipamento de dados } \\
\text { digitais }\end{array}$ \\
\hline Cerveja & Celulose & Fabricante de roupa & Consultoria jurídica \\
\hline Telefonia celular & Indústria têxtil & $\begin{array}{l}\text { Equipamento de } \\
\text { ginástica }\end{array}$ & Mídia \\
\hline Seguros & Seguro saúde & Serviços de limpeza & Carrinhos de golfe \\
\hline Energia & Aluguel de carros & Logística & Serviços de manutenção \\
\hline Serviços postais & Construtoras & $\begin{array}{l}\text { Recrutamento e } \\
\text { treinamento de } \\
\text { voluntários }\end{array}$ & Segurança \\
\hline $\begin{array}{c}\text { Total de } 300 \text { milhões } \\
\text { US\$ }\end{array}$ & $\begin{array}{l}\text { Total de } 140 \\
\text { milhões US\$ }\end{array}$ & Total de & milhões US\$ \\
\hline
\end{tabular}

Fonte - APO - Autoridade Pública Olímpica (2009).

Portanto os grandes grupos econômicos operam no território segundo lógicas oligopolistas, conseguindo marginalizar os outros atores envolvidos. Estes grandes grupos oligopolistas acabam por determinar uma reestruturação da economia urbana e regional, especialmente nos dois circuitos da economia urbana dos países subdesenvolvidos, o superior e o inferior (SILVEIRA, 2009).

O uso corporativo do espaço citadino afeta principalmente a população mais vulnerável socialmente, aumentando e agravando as condições de pobreza. Os governos realizam amplos investimentos para melhorar e modernizar o território e aprofundar a divisão internacional do trabalho, mas é necessário que estes investimentos econômicos apresentem um retorno do ponto de vista social também, o que normalmente não ocorre nos países subdesenvolvidos. Trata-se, pois, de uma modernização que exclui os mais pobres, os mais débeis da sociedade (ex. remoções, enobrecimento de alguns bairros, gentrification).

De acordo com Santos (2008), a cidade no mundo subdesenvolvido se configura por meio de paradoxos que dentre outros eventos geográficos materializa dois circuitos da economia urbana, o circuito inferior e o circuito superior, marcados por interdependência e complementaridade. O primeiro representado pelos sujeitos hegemonizados, oriundos da pobreza urbana, das periferias citadinas, incipiente em uso de capital, embora dinâmico e expressivo em fluxos de pessoas, produtos e serviços; enquanto o segundo apresenta uso intensivo de capital, representado pelos agentes hegemônicos da economia, os quais via de regra constituem o uso corporativo do território, portanto, o circuito moderno. No caso do circuito inferior, não importa onde o território é reorganizado, mas sua configuração se faz presente no contexto econômico citadino do mundo subdesenvolvido de forma marcante. Seus atores se agregam e se organizam no espaço urbano utilizando determinadas técnicas não modernas de produção do trabalho, baixo volume de capital e maneira específica de organizar-se (SANTOS, 2008)). Considerando que o circuito inferior e a pobreza são, de certo modo,

$\begin{array}{lllll}\text { Caminhos de Geografia } & \text { Uberlândia-MG } & \text { v. 21, n. } 74 & \text { Abr/2020 } & \text { p. 108-125 Página } 115\end{array}$ 
sinônimos, "é nesse circuito que a maior parte da população pobre encontra um abrigo, uma forma de se sustentar, pois exige menor volume de investimentos e não demanda, necessariamente, mão-deobra qualificada" (MEDEIROS, 2014, p. 116). Por outro lado, o circuito superior da economia urbana se desenvolve por meio de investimentos massivos de capital, fortemente articulado em rede, denso em técnica, informação e é altamente competitivo e hegemônico. Este circuito é marcadamente subsidiado e favorecido pelo Estado, pois além de subsidiar investimentos, legisla em favor dos seus agentes, além de consumir e demandar produtos e serviços aí produzidos e comercializados.

No contexto do uso corporativo do território, notadamente no âmbito da realização de eventos desportivos, o Estado geralmente não desenvolve políticas de interesse social, privilegiando e apoiando os interesses da FIFA, dos agentes corporativos e do COI. "O Estado renuncia às funções de regulação social e privilegia o seu papel de suporte da expansão das lógicas monetaristas" (SANTOS e SILVEIRA, 2001, p.305), desconsiderando as dinâmicas sociais e a atuação de políticas públicas de estímulo à cidadania e ao bem-estar coletivo.

Assim, depreende-se que por causa da mundialização do capital e dos diversos interesses econômicos em jogo, o Estado reduz ainda mais a sua preocupação com a cidadania e com os valores socio-territoriais, confundindo a figura do cidadão (força centrípeta) com a figura do consumidor (força centrifuga na localidade), seguindo ideologias espaciais distanciadas da realidade das populações e de suas reais necessidades.

Nesse sentido, um dos fatores mais importantes é a falta de compromisso com as demandas sociais e com os lugares. Ao discutir os vínculos entre cidades e estados para recompor os circuitos espaciais de produção, Silveira (2009, p. 448) relata:

\begin{abstract}
A falta de ligações entre os municípios e entre estados, províncias ou departamentos para recompor os circuitos espaciais de produção é também um elemento significativo. Nesse sentido, vale lembrar também o abandono do Estado em relação ao consumo social. Portanto, a globalização, como é aceita hoje na maioria dos países periféricos, significou um aumento nas polarizações sócio-espaciais. Seu corolário é a escassez de recursos, bens e serviços universais no resto do território e, consequentemente, um exercício desigual da democracia. (SILVEIRA 2009, p. 448)
\end{abstract}

Portanto, no mundo subdesenvolvido carece maior atenção aos anseios e demandas sociais de modo a garantir bens e serviços universais, com vistas ao bem-estar coletivo, através da construção de processos horizontais, democráticos, cujo papel do Estado se traduza em políticas, projetos e ações de desenvolvimento social e territorial.

Pelo que concerne o conceito de território normado, a Lei Geral da Copa e o Ato Olímpico constituem duas leis que concederam amplos direitos de atuação e operacionalização para a FIFA, o COI, o COB e seus principais parceiros comerciais, à desvantagem do próprio território assim como de outros sujeitos não hegemónicos envolvidos, tais como moradores do entorno das arenas, os pequenos vendedores, ambulantes, lojas menores e parte da população local. Antes, durante e depois da realização do megaevento, somente algumas empresas parceiras da FIFA e do COI tiveram e têm poder de utilização do território, de fato estas organizações esportivas, negociando com o Estado e com as Autarquias locais, conseguem condições novas, especiais e particulares como aconteceu com a FIFA durante a Copa do Mundo de 2014 (MEDEIROS, 2014) e com o COI nas Olimpíadas.

De fato, a FIFA, com o consenso e a aprovação do Governo brasileiro, através da "Lei Geral da Copa", criou um conjunto de leis ad hoc, fora da Constituição brasileira, para o período da organização e realização da Copa, onde somente os patrocinadores da FIFA podiam comercializar seus produtos durante o evento e não pagaram impostos para suas atividades no Brasil. No entanto, os pequenos comerciantes, os artistas de rua e milhares de trabalhadores ambulantes, não puderam vender nas áreas ao redor dos estádios e dos Fan Fest que eram vigiadas pelo exército e eram de total exclusividade da FIFA (MEDEIROS, 2014).Outrossim, ao redor dos estádios e das instalações esportivas existe também a geração de uma nova forma de manifestação do circuito inferior da economia urbana que acontece através de um número expressivo de comerciantes distribuídos tanto em estabelecimentos fixos como também ambulantes que, atentos à oportunidade de negócio, vendem variados tipos de alimentos e bebidas (MEDEIROS, 2014). Nesse sentido, observa-se que os entornos das estruturas esportivas, fora do raio de abrangência de uso exclusivamente da ação e competência dos parceiros comerciais das grandes organizações esportivas, são usados não somente como um dos principais lugares de lazer e diversão através dos Fan Fest e de outras atividades, mas também como um lugar de trabalho para muitos agentes (MEDEIROS, 2014).

$\begin{array}{lllll}\text { Caminhos de Geografia } \quad \text { Uberlândia-MG } & \text { v. 21, n. } 74 \quad \text { Abr/2020 } & \text { p. 108-125 Página } 116\end{array}$


A "Lei Geral da Copa" apresenta diversas obrigações e, ao mesmo tempo, contradições. O texto restringia especialmente o direito de ir e vir nos dias de jogo, pois os municípios tiveram que declarar feriados como suposta forma de reduzir os transtornos causados aos moradores da zona dos estádios. De fato, além de dispor de um ingresso, estes deviam ser munidos de uma acreditação para circular aos redores das arenas.

Segundo Rayes e Chahine (2014) no Jornal francês Libération, no mês de Maio de 2014, antes da Copa, a Corte Suprema julgou como constitucionais três pontos desta lei que tinham sido contestados pela Procuradoria-Geral da União do Governo Federal Brasileiro e, principalmente pelo fato de terem sido declarados feriados os dias em que decorriam os jogos, provocou um mal-estar geral entre os comerciantes locais.

Quanto aos Jogos Olímpicos do Rio de Janeiro de 2016, a Subchefia para Assuntos Jurídicos da Presidência da República instituiu o "Ato Olímpico", o qual estabeleceu:

No âmbito da administração pública federal, com a finalidade de assegurar garantias à candidatura da cidade do Rio de Janeiro a sede dos Jogos Olímpicos e Paraolímpicos de 2016 e de estabelecer regras especiais para a sua realização, condicionada a aplicação desta Lei à confirmação da escolha da referida cidade pelo Comitê Olímpico Internacional (BRASIL, 2009).

Trata-se de uma série de mudanças que foram operadas na ordem jurídica. De fato, através do "Ato Olímpico" foram concedidos diversos benefícios fiscais e creditícios para as organizações internacionais como o $\mathrm{COI}$, organizadores do evento e seus parceiros, prestadores de serviços e empreiteiras de construção civil; foram concedidas vantagens para a aquisição e utilização de bens públicos e instrumentos de controlo do espaço público para a proteção das marcas associadas aos eventos e para a tutela do chamado "marketing de emboscada" (OLIVEIRA, 2013, p.12-13), com o qual firmas não patrocinadoras e parceiras do $\mathrm{COI}$ e do $\mathrm{COB}$ tentavam aproveitar-se pegando "carona" do evento, cujos direitos já foram adquiridos por seus concorrentes pagando preços muito elevados para patrociná-los (APP BRASIL, 2016). Na referida lei do Ato Olímpico constavam algumas leis internas de proteção de direitos por parte do $\mathrm{COI}$ e do $\mathrm{COB}$ que proibiam a qualquer outro agente o aproveitamento de imagem, nome e, símbolos ligados aos Jogos Olímpicos, mesmo se ligados de forma indireta, podendo a sua inobservância resultar numa violação de direitos, passível de multa ou processo jurídico. No âmbito das marcas comerciais pertencentes ao $\mathrm{COI}$, ao qual compete o seu uso e licenciamento de direitos verifica-se as seguintes: Olímpico; Olimpíada; Jogos Olímpicos; Paraolímpico; Paraolimpíadas; Jogos Paralímpicos; Jogos Olímpicos; Rio 2016; Jogos Olímpicos e Paraolímpicos. Da mesma forma, precisa da autorização do COI (quando existe a finalidade comercial do uso) também o uso de desenhos, logos e outras imagens gráficas do megaevento, assim como os direitos relativos à bandeira e à tocha olímpica e também sobre as medalhas, mascotes, lemas e o próprio hino olímpico. Além disso, o COI proíbe também qualquer referência ou alusão feita às Olimpíadas através de propaganda publicitária efetuada por firmas que não constam na lista de parceiros, patrocinadores ou colaboradores das Olimpíadas e as violações a estes direitos são fundamentadas pelas seguintes legislações e normativas: Lei das Olimpíadas - Ato Olímpico (Lei n. 12.035/2009); Lei de Propriedade Industrial (Lei n. 9.279/1996); Lei do Direito Autoral (Lei n. 9.610/98); Tratado de Nairobi (Decreto n. 90.129/1984); Código Civil Brasileiro (Lei n. 10.406/2002); Código Brasileiro de Autorregulamentação Publicitária do Conselho de Autorregulamentação Publicitária; Código de Defesa do Consumidor (Lei n. 8.078/1990); Lei Pelé (Lei n. 9.615/1998) (OLIVEIRA, 2013). Outra norma, a "Regra 40" da Carta Olímpica, estabelece que "nenhum concorrente, treinador, instrutor ou funcionário que participa dos Jogos Olímpicos pode permitir que sua pessoa, nome, imagem ou atuações esportivas sejam explorados com fins publicitários durante os Jogos Olímpicos" (APP BRASIL, 2016, s.p.). Segundo esta norma, todos os atletas, técnicos e profissionais do exporte não podem realizar campanhas publicitárias das firmas que os patrocinam e que não são patrocinadores oficiais das Olimpíadas. Aqui tem-se mais um exemplo de um evento geográfico que ratifica a ideia do território como norma, isto é, o território normado.

O COI conta no momento com 13 patrocinadores do programa Top Partners do Comitê Olímpico Internacional. São marcas que, ao assinarem contrato com o COI, passaram automaticamente a patrocinar todos os 205 comitês olímpicos nacionais. Esses parceiros comerciais são: Coca-Cola, Alibaba Group, Atos, Bridgestone, Dow, GE, Mc Donald's, Omega, Panasonic, P\&G, Samsung, Toyota e Visa. Além desses grandes grupos e multinacionais, durante os Jogos Olímpicos do Rio de 
Janeiro de 2016 apoiaram o COI também a Nissan, a Bradesco, Bradesco Seguros, a Claro, a Embratel e a Nike (O ESTADÃO DE SÃO PAULO, 2017).

Esta dinâmica implica um uso privilegiado e hierárquico dos bens públicos, com um controle de tipo vertical, de cima para baixo, por parte das grandes corporações e organizações. Trata-se de um conceito que Santos e Silveira (2001, p. 295) definem como "espaço corporativo". Contudo, esta hierarquia pode mudar e transformar-se dependendo do contexto social, político e econômico e das novas variáveis geradas pela globalização, bem como pela racionalidade e/ou contra-racionalidades dos lugares. Quanto mais empoderadas e articuladas politicamente e socialmente as populações, maiores as possibilidades de mudanças desse cenário.

\title{
O CASO EMBLEMÁTICO DA VILA AUTÓDROMO
}

No âmbito desta vasta discussão sobre o uso do território associado aos megaeventos, o Rio de Janeiro ocupa lugar de destaque no cenário nacional, pois um dos pontos de maior conflito na fase de preparação e organização dos Jogos Olímpicos de 2016 sobressai o processo de remoção de assentamentos populares que na referida cidade ocorreu em diferentes áreas. Basta considerar que:

\begin{abstract}
Conforme denunciado por diversos movimentos sociais e organizações internacionais, tem sido frequente nestas ações do poder público, episódios de desrespeito às normas que regulam os deslocamentos involuntários, gerando inúmeros problemas para as populações atingidas, como aumento do deficit habitacional, desemprego e desestruturação de laços sociais (FREIRE, 2016, p. 77).
\end{abstract}

O caso da Vila Autódromo resulta ser emblemático porque constitui a única remoção reconhecida pela Prefeitura como efeito diretamente ligado à organização dos megaeventos esportivos, embora não tenha sido um caso isolado, tendo em vista os efeitos decorrentes. A Vila Autódromo é uma comunidade situada no bairro de Jacarepaguá, vizinha ao Parque Olímpico. O assentamento inicial surgiu como uma colonia de pescadores em 1967, depois, segundo o relato de dona Maria da Penha ${ }^{1}$ (2018) o povo foi se aglomerando, morando e criando famílias. Com o Autódromo de Jacarepaguá (Autódromo Nelson Piquet) a comunidade foi crescendo, tomando corpo e forma, aumentando consideravelmente nas últimas décadas do século XX. Teve gente que foi desapropriada de outras áreas como das favelas de Cardoso Fontes e de Cidade de Deus, e passou a morar nessa área (MUSEU DAS REMOÇÕES, 2016).De acordo com as fontes orais da pesquisa, desde os anos 1990 que os moradores da Vila Autódromo passaram a ser ameaçados e perseguidos, sobretudo pela Prefeitura do Rio de Janeiro. Existem relatos de moradores da Vila Autódromo que revelam já na década de 1990 tentativas de remoção da comunidade; o próprio Eduardo Paes que naquela época era subprefeito da Barra e de Jacarepaguá, tentou remover as famílias que, numa dada ocasião, ficaram até de madrugada resistindo e não deixaram os tratores entrarem para derrubar a comunidade. Na sequência a comunidade foi crescendo e, foi lutando pelos seus direitos. A Defensória Pública ajudou muito nesse aspecto, e em 1997 os moradores conseguiram um título, "a terra pra gente" (PENHA, 2018), ou seja uma concessão de uso de 39 anos. No mesmo ano, os moradores conseguiram uma outra concessão de uso mudando o título de posse de 39 anos para 99 anos, podendo ser prolongado por mais 99 anos, que concedia praticamente o direito de morar naquela área pelo resto da vida. Anos mais tarde, em 2005, a Câmara de Vereadores aprovou a lei complementar 74/2005, que transformou a comunidade em Área Especial de Interesse Social (PMMR, 2017; PENHA, 2018).Diversas foram as tentativas da Prefeitura no sentido de tirar a população da Vila Autódromo e desarticular toda a comunidade. Esse processo iniciou nos anos '90 com o pretexto de que o assentamento causava dano estético, urbano e ambiental ao bairro sendo declarada área de risco socio-ambiental (FREIRE, 2016). Mas, desde que o Rio de Janeiro foi escolhido como sede para a organização e realização de importantes megaeventos esportivos quais os Jogos Pan-americanos de 2007, a Copa do Mundo de Futebol de 2014 e o último e mais significativo para a cidade carioca, os Jogos Olímpicos de 2016, as ameaças por parte da Prefeitura e dos seus agentes tornaram-se constantes. Concomitantemente, a luta da população residente que não tinha intenção de deixar suas próprias habitações intensificou-se.

\footnotetext{
${ }^{1}$ Principal sujeito da pesquisa. Líder da Associação de Moradores da Vila Autódromo e Membro do Museu das Remoções e do Comitê Popular da Copa e das Olimpíadas.

Caminhos de Geografia

Abr/2020

p. $108-125$

Página 118
} 
Assim como relata um agente da pesquisa: "Quando saiu o anúncio que o Rio de Janeiro ia acolher as Olimpíadas, pensamos que a Vila Autódromo ia sofrer mais ainda porque eramos vizinhos do Parque Olímpico" (PENHA, 2018). De fato, em 2011 a Prefeitura do Rio de Janeiro anunciou a remoção de cerca de 500 famílias, alegando a alocação e construção do Parque Olímpico. Em 2014 começaram as demolições e remoções.

Segundo Freire (2016), a Prefeitura do Rio de Janeiro apresentou entre os objetivos do Plano Estratégico de Governo em 2009, a diminuição de 3,5\% dos territórios ocupados por comunidades carentes e favelas, processo que perdurou até o ano 2012. Entre esses territórios constavam a própria Vila Autódromo (porque estava vizinha ao Parque Olímpico) e a Favela do Metrô (nas redondezas do Maracanã). Essas duas comunidades foram as primeiras da lista por causa da própria vizinhança com as áreas afetadas pelas obras de infraestrutura para a Copa do Mundo de Futebol de 2014 e para os Jogos Olímpicos de 2016. Tal processo perdurou anos, pois de acordo com o agente da pesquisa: "Em 2005, por exemplo, eles vieram aqui e disseram queremos tirar por causa dos Jogos Pan-americanos de 2007, então eles vieram, a gente tinha quase certeza que eles tiravam a gente naquela época e não conseguiram" (PENHA, 2018).

Lutas intensas, resistência e conflitos fizeram parte do cotidiano das comunidades durante anos, basta atentar para os relatos dos sujeitos que participaram do processo, a exemplo do que segue:

"Lutando pela minha casa e pela casa dos outros, a gente acabava lutando pelo território todo. A gente começa a lutar e não sabe onde vai chegar. (...) Essa luta foi trabalhada há anos e anos. Eu faz 24 anos que moro aqui e faz 24 anos que estou sendo ameaçada" (PENHA, 2018). Conforme Regina Bienenstein (HUFFPOST BRASIL, 2016), arquiteta: "Em 2013 o prefeito chama as lideranças e diz que a solução de remoção não era a melhor e que quem quisesse poderia permanecer. Mas, contrariamente a essas declarações, a partir daí o que ocorreu foi o assédio e ameaça cotidiana dos moradores pela equipe da Prefeitura". Uma das formas de indenização foi conferir portanto apartamentos no condomínio Parque Carioca. Os primeiros moradores que saíram aceitaram esses apartamentos, depois outros moradores aceitaram indenizações milionárias. Nessa fase saiu da Vila Autódromo muita população. Embora a permanência da Vila Autódromo estava prevista no projeto internacional que definia o plano urbanístico do Parque Olímpico, em 2011 o Secretário Municipal de Habitação Jorge Bittar elaborou a proposta de reassentamento da população no vizinho Parque Carioca, um condomínio a $1 \mathrm{~km}$ de distância da Vila Autódromo.

De acordo com João Helvécio, defensor público: "As negociações tem um carater intimidatório e coercitivo e de pressão. As Olimpíadas são os jogos da exclusão, quem não está no perfil de acionista / consumidor está fora do jogo" (HUFFPOST BRASIL, 2016). Nessa luta, os mais débeis, pobres e vulneráveis são os que tem mais facilidade de ser corrompidos, cooptados ou de aceitar as propostas da Prefeitura de indenização ou de deslocamento para outra habitação.

\begin{abstract}
O dinheiro ele fala mais alto. Se eu posso pegar em 2 milhões, vou me dar bem, porque eu não posso pegar? Eu vou me dar bem, e quando você tem isso na mente, você perde o teu tesouro, que é o valor da tua história, o valor da tua terra, a sua dignidade, eu tenho dignidade. Dignidade não é moradia que te dá, você tem ela dada pelo próprio Deus. Então quando tu quer pescar, tu joga a melhor isca. Eles jogaram muitas iscas, fizeram várias formas para incentivar o povo. Então eles fizeram aquela propaganda maravilhosa que você ia morar com dignidade, puseram piscina com Tobo-água, então quando você é muito humilde você não tem noção, acha que está abafando, botaram pessoas trabalhando aqui dentro da comunidade, fazendo a cabeça das pessoas (PENHA, 2018).
\end{abstract}

Mas alguns moradores, como uma entrevistada e sujeito da pesquisa (PENHA, 2018), não aceitaram negociar afirmando que tinham título de posse do terreno concedido pelo governo estadual entre as décadas de '80 e '90. "Eu não quero sair, se eu tenho direito a ficar aqui, porque eu devo sair? Eu não vou sair. Nada obriga você a sair da sua casa. Não há nenhum tipo de processo judicial ou projeto formalizado" (PENHA, 2018).

A resistência ganhou o suporte de ativistas e teve repercussão na mídia internacional. Nesse contexto, para convencê-los a deixarem suas casas, a prefeitura induziu moradores a um acordo que não dava nenhuma garantia às famílias e as obrigava a abrirem mão de seus direitos. $O$ documento da prefeitura foi redigido de tal maneira que o morador que o assinava passava a propor a demolição da sua própria casa; ao mesmo tempo em que desistia das ações judiciais que o protegiam contra a remoção.

\begin{tabular}{|c|c|}
\hline Caminhos de Geografia & Uberlândia-MG \\
\hline
\end{tabular}


Segundo relatos de moradores: "A Olimpíada por onde ela passa, ela remove. Por todos os países onde ela passou, ela removeu, ela faz uma higienização social como se não permitisse pobres ao seu entorno" (HUFFPOST BRASIL, 2016).Emblemáticas são as palavras de uma entrevistada, sujeito da pesquisa: "Esse megaevento é para quem? Tem que ser para todos. A palavra Olimpíada quer dizer o quê? União dos povos. Mas que povo é esse que não é consultado?" (HUFFPOST BRASIL, 2016). A Prefeitura utilizou vários pretextos e justificativas para remover a comunidade, porque a terra era muito valiosa, e com o passar do tempo e com o advento dos megaeventos esportivos, ia se valorizando. Baste pensar que o metro quadrado na Vila Autódromo no período da remoção estava custando 10 mil reais (PENHA, 2018).

Os que mais desejam utilizar esse território e especular nele são as grandes empresas empreteiras e construtoras brasileiras porque existem áreas que são consideradas nobres, sobretudo aquelas ao longo da faixa marginal da lagoa de Jacarepaguá. Conforme o Comitê Popular da Copa e Olimpíadas do Rio de Janeiro (2015), todas essas construtoras são a Norberto Odebrecht, Andrade Gutierres e Carvalho Hosken e pertencem ao consórcio Rio Mais. De fato, para a construção da infraestrutura e parte das instalações, a prefeitura realizou uma concessão administrativa na modalidade Parceria Público-Privada (PPP), com prazo de vigência de 15 anos e, a única proposta apresentada, portanto vencedora, foi a do Consórcio Rio Mais. A Carvalho Hosken é também a principal proprietária de terras do entorno do Parque Olímpico, portanto, principal beneficiária da valorização imobiliária derivante das obras (COMITÊ POPULAR DA COPA E OLIMPÍADAS DO RIO DE JANEIRO, 2015). O consórcio é responsável pela implantação de toda a infraestrutura do Parque Olímpico, incluindo os três pavilhões do Centro Olímpico de Treinamento (COT), o Centro Internacional de Transmissão (IBC), o Centro de Mídia Impressa (MPC), um hotel e a infraestrutura da Vila dos Atletas mantendo a área por 15 anos (COMITÊ POPULAR DA COPA E OLIMPÍADAS DO RIO DE JANEIRO, 2015). Tal realidade pode ser constatada no relato de sujeito da pesquisa, quando surge a afirmação: "Por isso que nos querem tirar porque quando não tinha valor eles não queriam, eles não ligavam. Mas quando ficou valorizado e eles ampliaram a Barra pra cá, tudo mudou" (PENHA, 2018).

O envolvimento e os interesses do prefeito Eduardo Paes são evidentes, considerando as doações de construtoras das obras das Olimpíadas para ele no âmbito das eleições municipais de 2012 (FREIRE, 2016). De fato, entre as várias firmas que patrocinaram a campanha eleitoral do prefeito e do seu partido, o PMDB, durante as eleições municipais de 2012, constavam 3 construtoras que estavam diretamente envolvidas nas obras dos Jogos Olímpicos. Segundo o Tribunal Superior Eleitoral (G1 Globo, 2012), a principal doadora da campanha eleitoral foi a Carvalho Hosken Engenharia e Construções que auxiliou com 650.000 reais. A construtora era dona do terreno da Vila Olímpica e fazia parte do consórcio que construiu o Parque Olímpico em Jacarepaguá na área onde estava o antigo Autódromo Nelson Piquet. Outras construtoras envolvidas eram também a OAS, que pertencia ao Consórcio Porto Novo, responsável pela recuperação da Zona Portuária; e a Cyrela Monza Empreendimentos Imobiliários. Cada uma delas financiou a campanha eleitoral de Paes com 500.000 reais. Outras construtoras e imobiliárias também contribuíram com as doações, em particular a Multiplan Empreendimento Imobiliário com 500.000 reais, a MPH Empreendimento Imobiliário com 500.000 reais e a EMCCAMP Residencial com o valor de 400.000 reais (G1 GLOBO, 2012).

Segundo relatos de outro agente da pesquisa: "Em momento nenhum foi o esporte que nos ameaçou, o esporte e as Olimpíadas são o pretexto e o motivo. É triste, o esporte sendo usado por um fim tão hipócrita" (HUFFPOST BRASIL, 2016). Para outro morador: "Tudo o que fizeram aqui foi uma guerra social, uma disputa. Na verdade a Vila Autódromo não está sendo removida por causa das Olimpíadas". O que está por detrás das remoções são interesses especulativos. A retirada dos moradores deve-se atribuir à valorização dos imóveis na região, fenómeno ampliado com a chegada dos Jogos Olímpicos. Segundo o morador a questão é moral e não exclusivamente legal. "As pessoas pensam que a gente está brigando por causa dessas paredes. Mas as paredes não são nada. $\mathrm{O}$ que vale é o que a gente tem dentro da cabeça, o que nós somos, o que representa a não-aceitação da compra do poder público pela especulação imobiliária".

\section{O Plano Popular da Vila Autódromo}

Face a este cenário de remoção e expropriação, na tentativa de mostrar à Prefeitura que era possível que os moradores pudessem permanecer na Vila, um grupo de residentes pertencentes a Associação de Moradores e de Pescadores e Amigos da Vila Autódromo (AMPAVA), junto com a assessoria técnica de professores, estudiosos, pesquisadores, urbanistas, arquitetos, economistas, antropólogos e sociólogos de duas universidades públicas cariocas: a Universidade Federal do Rio de Janeiro 
(UFRJ) e a Universidade Federal Fluminense (UFF), trabalharam na elaboração de um plano alternativo de urbanização da Vila Autódromo que respondesse às exigências e às necessidades da população residente: o Plano Popular da Vila Autódromo (PPVA). Em particular, envolveram-se com a elaboração deste plano o Núcleo Experimental de Planejamento Conflitual do Laboratório Estado, Trabalho, Território e Natureza do Instituto de Pesquisa e Planejamento Urbano e Regional da Universidade Federal do Rio de Janeiro (NEPLAC/ETTERN/IPPUR/UFRJ) e o Núcleo de Estudos e Projetos Habitacionais e Urbanos da Universidade Federal Fluminense (NEPHU/UFF)."O Plano afirma a existência da comunidade, e o direito de continuar existindo, com condições adequadas de urbanização e serviços públicos: o direito ao desenvolvimento urbano, econômico, social e cultural" (AMPAVA, 2012, p. 5).

A elaboração do plano popular de urbanização consistiu numa nova forma de planejamento com metodologia e estratégias diferentes baseadas fundamentalmente no planejamento por parte da população, um planejamento do povo, popular. Desta forma, o planejamento urbano evita ser um mero monopólio à mercê de políticos e tecnocratas, tornando-se uma ferramenta de luta da comunidade. O Plano Popular contemplava a urbanização completa da área, bem como a reforma e a ampliação da sede da Associação dos Moradores, da creche, de praças e de outras áreas de lazer. Oferecia ainda soluções variadas - tanto de apartamentos quanto de localização - às famílias que precisavam de reassentamento. Até agora ninguém viu o Estudo de Impacto Ambiental do Parque Olímpico e das obras de ampliação das avenidas Salvador Allende e Abelardo Bueno: os moradores não foram ouvidos.

O Plano Popular era viável, integrava a comunidade ao Parque Olímpico e à vizinhança e respeitava os direitos dos moradores! O projeto venceu um concurso internacional promovido por uma instituição alemã e tinha um custo estimado de cerca de 13,5 milhões de reais (quadro 1). Segundo Penha (2018), a Prefeitura gastou quase 300 milhões de reais para remover a comunidade, mas ficava muito mais barato urbanizar toda a comunidade e deixar um verdadeiro legado social das Olimpíadas. Juntamente com o Plano Popular de Urbanização da Vila Autódromo, em 2013 foi criado um Parecer sobre as propostas de urbanização da Associação de Moradores da Vila Autódromo e de reassentamento da Prefeitura da Cidade do Rio de Janeiro para os moradores da Vila Autódromo por parte de um Grupo de Trabalho Acadêmico Profissional Multidisciplinar (GTAPM). Conforme o documento que foi elaborado, as remoções na Vila Autódromo representariam somente o efeito de vários interesses, sobretudo de natureza econômica, das grandes empreiteiras e construtoras envolvidas no processo de especulação imobiliária de toda a área. Estas ações de higienização social seriam totalmente desnecessárias, além de ter custos sociais e econômicos bem mais caros se comparadas com a proposta do Plano Popular da AMPAVA (GTAPM, 2013). Infelizmente tanto o Plano Popular de Urbanização como o Parecer do GTAPM, não foram tomados em consideração pela Prefeitura.

"A despeito de o discurso oficial afirmar que a população é a grande protagonista dos Jogos Rio 2016, em várias das intervenções urbanas realizadas a participação da sociedade é praticamente nula" (FREIRE, 2016, p. 76).

\section{Uma contextualização sobre a situação atual}

O que resta agora da Vila Autódromo são 20 casas, com dois quartos, banheiro e cozinha que foram entregues uma semana antes do começo dos Jogos Olímpicos pela Prefeitura e foram construídas a poucos metros de distância de onde as demolições aconteceram. A luta portanto não foi em vão, o caso da Vila Autódromo em função da resistência dos moradores foi um processo violento mas mais favorável aos moradores que inclusive conseguiram permanecer, embora com um número limitado. Mas a maior parte das famílias foi removida, atendendo aos interesses do mercado imobiliário.

Do ponto de vista dos problemas e danos ambientais, a lagoa de Jacarepaguá foi afetada pelas obras do Parque Olímpico, de fato antes a faixa marginal da lagoa apresentava vegetação, ao passo que hoje praticamente não existe ou é muito insignificante comparado ao que era.

Observando as Figuras 2, 3, 4 e 5, pode-se perceber como o espaço e o território da Vila Autódromo foram mudando de forma considerável a partir do ano 2010, quando começaram as obras para a realização do Parque Olímpico, até o ano 2018 (dois anos após a realização do megaevento). Na Figura 5 é possível observar que toda a faixa marginal arborizada e habitada ao longo da lagoa foi completamente retirada e que, de toda a população da Vila Autódromo (nas Figuras 2 e 3) só

Caminhos de Geografia $\quad$ Uberlândia-MG $\quad$ v. 21, n. 74 Abr/2020 $\quad$ p. 108-125 Página 121


permaneceram 20 famílias. E tudo isso para deixar espaço para um estacionamento (quase sempre inutilizado) e algumas infraestruturas que agora estão semiabandonadas.
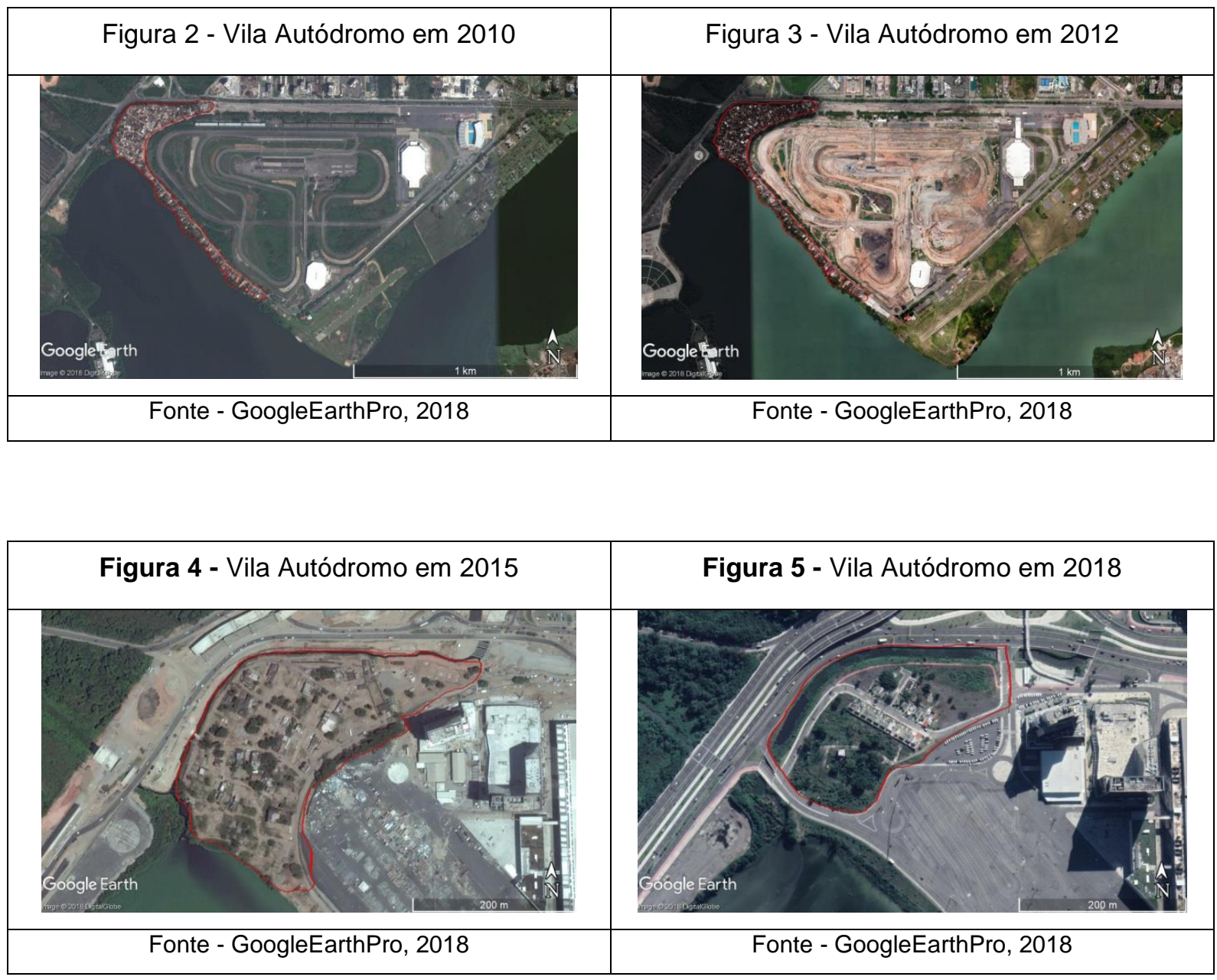

As 20 famílias que resistiram e permaneceram na Vila Autódromo constituem o símbolo de uma luta que representa a luta de muitos cariocas dada a importância dessa para outras lutas e resistências populares contra remoções arbitrárias. De fato um processo de melhorias no sistema urbano da Vila Autódromo poderia ter sido um legado, urbanizando a comunidade com base nas sugestões do Plano Popular e não a remoção das famílias do território construído durante décadas de trabalho e luta. "Na verdade essa comunidade nem precisava tirar. Teria sido um exemplo importante de como fazer Olimpíadas. Esse teria sido o legado verdadeiro" (PENHA, 2018).

\section{CONSIDERAÇÕES FINAIS}

Durante todo o trabalho, viu-se como a organização e realização de megaeventos esportivos como, em particular, os Jogos Olímpicos do Rio de Janeiro de 2016, se traduz em estratégia de desenvolvimento ligada ao modelo de gestão empresarial do território, tornando-se capaz de produzir uma vasta movimentação de capitais econômicos, causando rupturas e realinhamentos nas várias dimensões da sociedade e nas cidades influenciadas por esse fenômeno. Os dados examinados indicam que, ao se constituir como universo social autônomo em relação a pressões externas, o campo onde se produz o megaevento, serve como instrumento para submeter o território e seus residentes às pressões do setor econômico e do capital internacional.

De fato, a preocupação das autoridades governamentais, dos organizadores e das grandes organizações esportivas como a FIFA, o COI e os seus principais parceiros comerciais, que correspondem aos grupos hegemônicos em estudo, não reside nas transformações objetivas do 
território, visando a melhoria das condições de vida dos residentes, mas nas ações que, com o pretexto de recuperar a imagem do território, tendem a cuidar somente dos próprios interesses e ao lucro. O espaço urbano assume sempre mais uma conotação mercadológica com contornos empresariais. Para a produção desse novo espaço, atuam diversos intervenientes e interesses. A cidade é, portanto tratada como mercadoria e passa a ser pensada de forma a atender as necessidades de um determinado tipo de consumidor como o capital internacional, visitantes e usuários que possam pagar. Dessa forma, pode-se constatar que o interesse particular de poucos, nessa dinâmica de transformações espaciais da cidade, prevalece sobre à coisa pública e ao interesse da população local.

Conforme as informações apresentadas, o contexto político-institucional constituído para a organização dos megaeventos (em particular no Brasil) instaura uma situação de exceção, tanto relativamente aos ordenamentos jurídicos e políticos, quanto pelo que concernem as práticas políticas para sua efetivação.

Com relação à divisão territorial e social do trabalho ressalta-se a presença de uma serie de agentes hegemônicos que operam no âmbito dos megaeventos esportivos, desde as grandes multinacionais parceiras da FIFA e do COI, que são favorecidas pelas leis promulgadas e citadas anteriormente e prevalecem sobre os sujeitos não hegemônicos, que não detém nenhum tipo de poder de decisão, como os vendedores menores e informais, atores pertencentes ao circuito inferior da economia.

Em conclusão, pode-se afirmar que não existe um correto planejamento no processo de organização de um megaevento esportivo como a Copa do Mundo de Futebol ou uma Olimpíada se não se efetua uma correta gestão em racionalidade do território, ou seja, das ações que sobre ele se realizam. Viuse como, durante um megaevento, o espaço nacional é submetido, com o consenso dos governos locais, a serviço das grandes organizações esportivas e empresas que visam somente a obtenção de uma produtividade e lucro sempre maiores, a desvantagem dos outros sujeitos e da população residente.

Por isso, é preciso uma mútua colaboração e cooperação entre os diferentes atores envolvidos no processo, desde o Estado, passando pelos Governos nos diferentes níveis, pelos organizadores do evento, pelas organizações esportivas, pelas empresas públicas e privadas até chegar aos sujeitos do circuito inferior da economia urbana e aos moradores.

Ocorre uma solidariedade de tipo orgânica e não somente organizacional, que seja efeito da interdependência entre agentes e ações resultantes da sua existência no território usado e apontando para um destino comum, com mais transparência limitando e evitando a corrupção.

Para ultrapassar essa problemática é preciso ações políticas coerentes e integradas territorialmente. Integradas quer dizer, consonante com os interesses da coletividade, com o bem-comum, com melhorias e benefícios do ponto de vista social também. É necessário portanto inserir os megaeventos num plano de desenvolvimento global e integrado da cidade (urbano/territorial + social).

\section{REFERÊNCIAS}

AMPAVA - Associação de Moradores, Pescadores e Amigos da Vila Autódromo. Plano Popular da Vila Autódromo. Plano de Desenvolvimento Urbano, Econômico, Social e Cultural, 2012.

APO - Autoridade Pública Olímpica. Dossiê de candidatura do Rio de Janeiro a sede dos Jogos Olímpicos e Paraolímpicos de 2016. Disponível em http://www.apo.gov.br/index.php/matriz/amatriz-e-o-dossie-de-candidatura/ Acesso em 05/07/2018. 2009.

APP BRASIL - Associação dos Profissionais de Propaganda. Publicidade com vinculação aos Jogos Olímpicos do Rio de Janeiro 2016. Disponível em: http://appbrasil.org.br/noticias-eartigos/artigos/publicidade-com-vinculacao-aos-jogos-olimpicos-do-rio-de-janeiro-2016/]. Acesso em 20-01-2018.

BRASIL. PRESIDÊNCIA DA REPÚBLICA. CASA CIVIL. SUBCHEFIA PARA ASSUNTOS JURÍDICOS. Lei no 12.035, de 1ํ de outubrode 2009. Institui o Ato Olímpico, no âmbito da administração pública federal, com a finalidade de assegurar garantias à candidatura da cidade do Rio de Janeiro a sede dos Jogos Olímpicos e Paraolímpicos de 2016 e de estabelecer regras especiais para a sua realização, condicionada a aplicação desta Lei à confirmação da escolha da referida cidade pelo Comitê Olímpico Internacional. Brasília: Presidência da República, 2009. 
BRENNER, N. Urban theory without an outside. In: study of planetary urbanization. Berlim: Jovis, 2014. p. 14-30.

(Ed.). Implosions/Explosions: towards a

CHESNAIS, F. A mundialização do capital. São Paulo: Xamã, 1996.

COMITÊ POPULAR DA COPA E OLIMPÍADAS DO RIO DE JANEIRO. Dossiê Megaeventos e Violações de Direitos Humanos no Rio de Janeiro, 2015.

EGLER, T. A rede olímpica no jogo do Rio. In Encontro Nacional da Associação Nacional de PósGraduação e Pesquisa em Planejamento Urbano e Regional - XVII ENANPUR, 2017, São Paulo. Anais, Sessão temática 10, São Paulo: FAUUSP, 2017.

ESSEX, S.; CHALKLEY, B. Mega-sporting events in urban and regional policy: a history of the Winter Olympics. London: Planning Perspectives. 19(2), 201-232, 2004.

https://doi.org/10.1080/0266543042000192475

FREIRE, L. Quando a "cidade olímpica" não é para todos: o caso da Vila Autódromo, Rio de Janeiro: Advir 35, ISSN 1518-3769, Julho de 2016.

G1 GLOBO. "Paes recebeu doações de construtoras olímpicas". Disponível em https://oglobo.globo.com/brasil/paes-recebeu-doacoes-de-construtoras-olimpicas-6691264 09-112012

GOOGLE. Google Earth Pro. Disponível em: http://earth.google.com/, 2019. Acesso em 20/01/2018.GTAPM - Grupo de Trabalho Acadêmico Profissional Multidisciplinar. Parecer sobre as propostas de urbanização da Associação de Moradores da Vila Autódromo e de reassentamento da Prefeitura da Cidade do Rio de Janeiro para os moradores da Vila Autódromo, 2013.

HARVEY, D. A produção capitalista do espaço. São Paulo, Annablume, 2005.

HARVEY, D. Espaços de Esperança. 3. ed. São Paulo: Edições Loyola, 2009.

HILLER, H. Mega-Events, Urban Boosterism and Growth Strategies: An Analysis of the Objectives and Legitimations of the Cape Town 2004 Olympic Bid. Cape Town: International Journal of Urban and Regional Research, 24 (2), 449-458, 2000. https://doi.org/10.1111/1468-2427.00256

HUFFPOST BRASIL. Vila Autódromo: Medalha de ouro em resistência. YouTube, 03 de Agosto de 2016. Disponível em https://www.youtube.com/watch?v=-oiX5eM1kk8. Acesso em 10 de Outubro de 2018.

MARX, K. O capital. São Paulo: Abril Cultural, v. 1, livro 1, tomo 1, 1983.

. O capital. São Paulo: Abril Cultural, v. 1, livro 1, tomo 2, 1984.

MEDEIROS, T. O turismo de sol e praia e o circuito inferior da economia urbana: um estudo a partir da praia de Ponta Negra - Natal/RN. Dissertação (Mestrado em Geografia) - Universidade Federal do Rio Grande do Norte, Natal, Brasil, 2014.

MUSEU DAS REMOÇÕES. A Vila Autódromo. Disponível em https://museudasremocoes.com/\#, 2016. Acesso em 17 de Janeiro de 2020.

O ESTADÃO DE SÃO PAULO. COB perde patrocinadores e inicia ciclo olímpico para Tóquio sem parceiros comerciais próprios. Publicado em 16 de fevereiro de 2017. Disponível em: $<$ http://esportes.estadao.com.br/noticias/jogos-olimpicos,cob-perde-patrocinadores-e-inicia-cicloolimpico-para-toquio-sem-parceiros-comerciais-proprios,70001668290>. Acesso em 20 de Janeiro de 2018.

OLIVEIRA, N. A produção da cidade através do espetáculo esportivo: quando a exceção se torna regra. Rio de Janeiro: E-Metropolis - Revista eletrônica de estudos urbanos e regionais, n.13, ano 4, Junho de 2013.

PENHA, M. Transformações socio-territoriais na Vila Autódromo. Rio de Janeiro, 28/06/2018. Entrevista não confidencial concedida a Roberto Paolo Vico.

PMMR - Plano Museológico do Museu das Remoções. Texto coletivo, escrito por Sandra Maria de Souza Teixeira, Nathalia Macena, Luiz Cláudio da Silva e Maria da Penha Macena, 2017. Disponível em https://drive.google.com/file/d/1B_BQsCbn9xYuwp1NrutIAYxYuCKj8sXn/view. Consultado em 09/07/2019. 
RAYES, C.; CHANINE, M. Les exclus du Mondial. Libération, Paris, pp. 2-5, 10 jun. 2014.

SANTOS, M. Espaço e método. São Paulo: Nobel, 1992.

Por uma outra globalização: do pensamento único à consciência universal. 11. ed. Rio de Janeiro: Record, 2004.

O espaço dividido: Os dois circuitos da economia urbana dos países subdesenvolvidos. São Paulo: Edusp - Editora da Universidade de São Paulo, 2008.

A Natureza do Espaço. 4. ed. São Paulo: Editora da Universidade de São Paulo, 2012.

SANTOS, M.; SILVEIRA, M. L. O Brasil: Território e Sociedade no Início do Século XXI. Rio de Janeiro: Récord, 2001.

SILVEIRA, M. L. Los territorios corporativos de la globalización. Buenos Aires: Memoria Académica. Universidad Nacional de la Plata, Faculdad de Humanidades y Ciencias de la Educación. Vol.3, n.3, 13-26, 2007. ISSN 1850-1885.

Región y división territorial del trabajo: desafíos en el período de la globalización. Puerto Colombia: Investigación y desarrollo, 17, 2 - ISSN 0121-3261, 2009.

.Espaço geográfico e fenômeno técnico: pensando um esquema de análise. In: BOMFIM, Paulo Albuquerque; SOUSA NETO, Manoel Fernandes (Org.). Geografia e pensamento geográfico no Brasil. São Paulo: Annablume, p. 123-139, 2010.

Circuitos de la economía urbana: ensayos sobre Buenos Aires y São Paulo. Ciudad Autónoma de Buenos Aires: Café de las Ciudades, 2016.

VAINER, C.B. Pátria, empresa e mercadoria: notas sobre a estratégia discursiva do planejamento estratégico urbano. In: ARANTES, $O$. et al. A cidade do pensamento único: desmanchando consensos. Petrópolis: Vozes, 2000.

VICO, R. P. Os megaeventos desportivos na percepção da comunidade local: o caso do Mundial de Futebol do Brasil de 2014 pelos moradores de Itaquera em São Paulo. Dissertação (Mestrado em Turismo e Gestão Estratégica de Destinos Turísticos) - Escola Superior de Hotelaria e Turismo do Estoril, Portugal, 2016.

VICO, R. P.; UVINHA, R.; GUSTAVO, N. Sports mega-events in the perception of the local community: the case of Itaquera region in São Paulo at the 2014 FIFA World Cup Brazil. London: Soccer \& Society, vol. 19, n. 2, February 2018. DOI: 10.10080/14660970.2017.1419471 Disponível em: <https://doi.org/10.1080/14660970.2017.1419471 . Acesso em janeiro de 2018.

Recebido em: 15/07/2019

Aceito para publicação em: 28/02/2020 